\title{
Współczesne problemy krajów Europy Zachodniej z perspektywy teorii Mancura Olsona
}

DOI: $10.19195 / 1643-0328.27 .3$

Słowa kluczowe: grupy interesu, lobbing, Olson, Europa Zachodnia, UE, kryzys gospodarczy

\section{Wprowadzenie}

W ostatnich latach większość krajów Europy Zachodniej zmaga się z poważnymi problemami. Najbardziej widoczne z nich mają charakter ekonomiczny i polityczny: długotrwała stagnacja gospodarcza, kryzys projektu integracyjnego oraz wzrost politycznej niestabilności przejawiający się na przykład w upadku stabilnego systemu partyjnego w wielu krajach ${ }^{1}$.

Jeszcze kilkanaście lat temu na Starym Kontynencie powszechnie wyrażano nadzieję, że pogłębiona ekonomiczna i polityczna integracja oraz wewnętrzne reformy zapoczątkują okres przyspieszonego wzrostu gospodarczego, a stabilność instytucji politycznych była uważana za trwałe osiągnięcie krajów europejskich. Przykładem może być przemówienie wygłoszone przez ówczesnego komisarza UE do spraw rynku wewnętrznego i późniejszego premiera Włoch Mario Montiego w 1998 roku. Z jednej strony zwraca on

${ }^{1}$ Na przykład podczas wyborów prezydenckich w Austrii w 2016 roku do drugiej tury nie przeszedł żaden z kandydatów reprezentujących dwie dominujące od kilkudziesięciu lat partie (ÖVP i SPÖ). Również w Hiszpanii podczas wyborów parlamentarnych w 2016 roku nowe ruchy polityczne, takie jak Unidos Podemos czy Ciudadanos, naruszyły dotychczasowy „duopol” PSOE i PP. Natomiast w takich krajach, jak Niemcy czy Szwecja, szokiem dla opinii publicznej było uzyskanie kilkudziesięciu mandatów w ostatnich wyborach parlamentarnych przez partie, które jeszcze dekadę wcześniej w ogóle nie miały parlamentarnej reprezentacji (odpowiednio AfD i Szwedzcy Demokraci). W wypadku Włoch już wcześniej trudno było mówić o stabilności, jednak dojście do władzy Ruchu Pięciu Gwiazd, istniejącego od 2009 roku (w koalicji z Ligą Północną), było dla wielu analityków zaskoczeniem. W ciągu ostatniej dekady zatem w wielu krajach kontynentu można obserwować szybki wzrost znaczenia partii nowo powstałych (i niebędących kontynuatorkami wcześniej istniejących ugrupowań) lub znajdujących się wcześniej na marginesie życia politycznego oraz spadek znaczenia do niedawna dominujących partii centroprawicowych i centrolewicowych. 
uwagę na gospodarcze problemy Europy, takie jak zbyt wysokie bezrobocie, szczególnie wśród młodzieży, czy niska konkurencyjność w porównaniu z USA, z drugiej zaś mówi o widocznych korzyściach $\mathrm{z}$ „europejskiej kultury stabilności” oraz wyraża przekonanie, że rychłe wprowadzenie wspólnej europejskiej waluty „Zwiększy zaufanie konsumentów i inwestorów” i zaowocuje „bardziej dynamicznym wspólnym rynkiem, szybszym tempem wzrostu gospodarczego i większą ilością miejsc pracy”2. Jeśli weźmiemy pod uwagę tempo wzrostu gospodarczego, poziom bezrobocia i stabilność makroekonomiczną w ostatnich latach w takich krajach strefy euro, jak Grecja, Włochy, Hiszpania czy Francja, trudno nazwać prognozę włoskiego polityka trafną.

Z kolei pierwsze lata wielkiego światowego kryzysu gospodarczego, mającego swoją kulminację w latach 2008-2009, przyniosły nadzieję, że będzie on impulsem do przyspieszenia procesu integracji i reform wewnętrznych ${ }^{3}$.

Co mogło sprawić, że te nadzieje się nie spełniły?

Celem pracy jest wykorzystanie teorii Olsona do wyjaśnienia gospodarczych i politycznych problemów występujących w krajach Europy Zachodniej w ciągu ostatnich dwóch dekad. Główna teza, którą próbuję zweryfikować w niniejszym artykule, jest taka, że opisane wcześniej problemy, pozornie dotyczące głównie sfery ekonomicznej i politycznej, mają w istocie głębsze podłoże natury społecznej. Ponadto można przypuszczać, iż mamy do czynienia $\mathrm{z}$ długotrwałymi procesami, które wcale nie są bezprecedensowe, lecz występowały już wcześniej w innych krajach i epokach.

W pierwszym rozdziale przedstawię teorię, która może pomóc w odpowiedzi na postawione pytania. Następnie postaram się za jej pomocą opisać i wyjaśnić główne problemy obserwowane w krajach Europy Zachodniej w ostatnich latach.

\section{Teoria Olsona}

Mancur Olson (1932-1998) był amerykańskim ekonomistą znanym dzięki swoim pracom, znacznie jednak wykraczającym poza ramy wąsko rozumianych badań ekonomicznych, poruszającym zagadnienia z dziedziny socjologii, politologii czy nawet filozofii historii. Jego prace i idee przyniosły mu rozgłos i sławę wychodzącą poza wąskie grono specjalistów, o czym mogą świadczyć poświęcone temu uczonemu artykuły opublikowa-

2 Przemówienie wygłoszone przez M. Montiego 27 listopada 1998 roku na konferencji „Kangaroo Group", http://europa.eu/rapid/press-release_SPEECH-98-272_en.htm (dostęp: 11.04.2018).

3 Tego rodzaju nadzieje były szczególnie silne w szczycie kryzysu w strefie euro w 2011 roku. Choć z jednej strony powszechnie wyrażano obawy dotyczące najbliższej przyszłości projektu integracyjnego, to z drugiej oczekiwano „ucieczki do przodu” w postaci wejścia na poziom unii politycznej, na przykład poprzez stworzenie czegoś w rodzaju wspólnego rządu dla strefy euro lub nawet przekształcenia jej w państwo federalne. Tego rodzaju wizje snuli między innymi kanclerz Angela Merkel i ówczesny prezydent Francji Nicolas Sarkozy: L. Elliott, G. Wearden, Merkel and Sarkozy Push for greater European co-operation. European summit calls for creation of eurozone president and balanced budgets, „The Guardian” 17.08.2011, http:// www.theguardian.com/business/2011/aug/17/angela-merkel-nicolas-sarkozy-summit (dostęp: 11.04.2018); Sarkozy eyes two-speed future for Europe, „Reuters” 8.11.2011, http://www.reuters.com/article/usfrance-eurozone/sarkozy-eyes-two-speed-future-for-europe-idUSTRE7A75PN20111108 (dostęp: 13.04.2018). 
ne po jego śmierci w takich gazetach, jak „The Economist”, „The Independent” czy „New York Times”. W swojej najbardziej znanej książce Logika działania zbiorowego. Dobra publiczne i teoria grup ${ }^{4}$ przedstawił on kompleksową teorię opisującą wpływ aktywności różnych grup interesu na politykę państwa oraz mechanizmy działania organizacji zrzeszających ich członków (na przykład związków zawodowych).

W swojej pracy chciałbym się skupić na pewnych aspektach teorii Olsona, jednak uważam za konieczne zaprezentowanie również jej ogólnych założeń. Poniżej przedstawiłem w skrócie te, które uważam za najistotniejsze ${ }^{5}$ :

1. Ludzie zrzeszają się, gdyż mają pewne wspólne interesy, które chcą realizować. Nie robią tego jedynie $\mathrm{z}$ troski o indywidualne dobro - o to przeważnie można zabiegać skuteczniej bez przynależności do organizacji.

2. Amerykański ekonomista zauważa, że niekiedy racjonalne jednostki, kierując się podczas podejmowania decyzji egoistycznym interesem, doprowadzają do sytuacji, w której wszyscy ponoszą straty (Olson wskazuje, iż racjonalne działania poszczególnych przedsiębiorców w warunkach konkurencji doskonałej mogą doprowadzić do ograniczenia zysków każdego z nich).

3. Aby uniknąć sytuacji przedstawionej w punkcie 2, logicznym rozwiązaniem jest podjęcie zbiorowego działania (na przykład stworzenie lobby zabiegającego o rządową interwencję na rynku).

4. Jednak $\mathrm{w}$ większych grupach $\mathrm{w}$ indywidualnym interesie jednostek nie jest angażowanie się $\mathrm{w}$ takie działania, gdyż wiąże się to z zauważalnym kosztem przy niedostrzegalnym wpływie na ich skuteczność (na przykład przedsiębiorca nie ma powodów, by sądzić, że jego nieprzystąpienie do grupy zrzeszającej wszystkich pracodawców będzie miało negatywny wpływ na skuteczność działania takiej struktury).

5. $\mathrm{Z}$ argumentacji przedstawionej w punkcie 4 wynika, że w dużych organizacjach muszą istnieć dodatkowe bodźce utrzymujące przynależność i aktywność członków w postaci różnych form przymusu i zachęt. Skuteczność i efektywność działania dużych grup interesu jest zatem niższa niż małych.

6. W rezultacie jednym z podstawowych problemów jest sprzeczność między potrzebą reprezentowania interesów dużych grup a brakiem motywacji do działalności w ich obrębie z punktu widzenia racjonalnej ekonomicznie jednostki. Olson podaje tutaj przykład dużych związków zawodowych, których aktywność większość pracowników uważa za pożyteczną, jednak najczęściej nie chcą oni dobrowolnie poświęcać swojego czasu na działalność w nich, uważając, że ich indywidualne zaangażowanie nie ma większego znaczenia w tak dużej organizacji.

Jednak aspektem, na którym chciałbym się skoncentrować w niniejszej analizie, jest stworzona przez amerykańskiego uczonego teoria dotycząca rozwoju społeczeństw, przedstawiona w książce Wzrost potegi i schyłek państw (The Rise and Decline of Nations). Olson wykorzystuje tutaj swoje obserwacje dotyczące aktywności różnego rodzaju grup interesu do wyjaśnienia wielkich procesów historycznych.

Zdaniem Olsona grupy interesu dzielą się zasadniczo na: koalicje dystrybucyjne (distributional coalitions) i koalicje inkluzywne (encompassing coalitions). Pierwsze z nich są tworzone przez stosunkowo niewielką grupę osób, która dąży do realizacji własnych interesów i uzyskania przywilejów. Dzieje się to najczęściej kosztem interesów reszty społeczeństwa ${ }^{6}$.

Koalicje dystrybucyjne są łatwiejsze do sformowania, nie tylko dlatego że mają mniej członków, ale również ze względu na to, że charakteryzują się większą jednorodnością (na przykład przemysłowcy z określonej branży). Motywacja do uczestnictwa w takiej

\footnotetext{
${ }^{4}$ M. Olson, The Logic of Collective Action. Public Goods and the Theory of Groups, Cambridge 2002.

${ }^{5}$ Ibidem, s. 5-22, 36-52, 53-57.

${ }^{6}$ M. Olson, Aufstieg und Niedergang von Nationen, Tybinga 1985, s. 52-68.
} 
grupie i jej potencjalna skuteczność jest wysoka, gdyż ewentualne korzyści są rozdzielane wśród niewielkiej liczby członków, podczas gdy koszty ponoszone przez resztę społeczeństwa wydają się małe (a więc motywacja, by im przeciwdziałać, również jest słaba $)^{7}$. Żeby lepiej zilustrować tę prawidłowość, posłużę się przykładem. Jeśli lobby producentów cementu doprowadzi do wprowadzenia ceł importowych na ten produkt, właściciele cementowni odniosą wyraźne korzyści - będą mogli zwiększyć sprzedaż i podnieść ceny, nie będą również musieli się obawiać wyparcia z krajowego rynku przez zagraniczną konkurencję. Natomiast reszta społeczeństwa poniesie dość niewielką stratę - wzrośnie cena jednego $\mathrm{z}$ wielu produktów dostępnych na rynku. Z punktu widzenia większości konsumentów zachęta do potencjalnego przeciwdziałania wysiłkom lobby producentów jest zatem niewielka.

Organizacje inkluzywne natomiast różnią się głównie tym, że choć również reprezentują interesy określonej grupy, to stanowi ona znaczną część społeczeństwa. Typowym przykładem organizacji należącej do tej kategorii mogą być związki zawodowe zrzeszające znaczną część zatrudnionych, organizacje pracodawców grupujące dużą część przedsiębiorstw czy organizacje konsumenckie. Dzięki temu, że ich interesy dotyczą znacznej części gospodarki, są one zainteresowane jej ogólnym rozwojem. O ile jest jak najbardziej możliwe, by niewielka grupa wyraźnie zwiększała swoją zamożność w sytuacji gdy gospodarka znajduje się w stanie recesji, o tyle trudno sobie wyobrazić, by podobna sytuacja dotyczyła na przykład $40 \%$ zatrudnionych czy pracodawców. Z punktu widzenia racjonalności ekonomicznej organizacje inkluzywne powinny troszczyć się nie tylko o realizację własnych interesów, lecz także o to, by koszty tego były jak najmniejsze dla reszty społeczeństwa ${ }^{8}$.

Z ogólnej teorii dotyczącej grup interesu, przedstawionej w punktach 1-6, wynika, że mniejsze grupy są efektywniejsze, a ich członkowie mają większą motywację do działania. Koalicje dystrybucyjne są więc łatwiejsze do sformowania i przeważnie skuteczniejsze niż koalicje inkluzywne. W efekcie w większości społeczeństw występuje tendencja do kumulowania się z czasem tych pierwszych. Prowadzi to do spadku efektywności gospodarki, gdyż organizacje tego rodzaju są w stanie narzucić rozwiązania niekorzystne dla większości społeczeństwa w celu realizacji własnych interesów. Dla takich organizacji dystrybucyjnych, jak kartel, lobby branżowe, gildia czy stowarzyszenia zrzeszające przedstawicieli „wolnych zawodów”, korzystne może być na przykład ograniczenie konkurencji, zmniejszenie produkcji, ograniczenie dostępu do wykonywania określonych zawodów czy przeciwdziałanie innowacyjności zagrażającej istniejącym przedsiębiorstwom ${ }^{9}$. Ponadto działalność takich grup prowadzi do tego, że gwałtownie narasta liczba państwowych regulacji i następuje biurokratyzacja gospodarki ${ }^{10}$. Wszystkie tego rodzaju utrudnienia prowadzą do spowolnienia tempa wzrostu gospodarczego.

\footnotetext{
7 Ibidem, s. 52.

8 Ibidem, s. 62-65.

9 Ibidem, s. 81-87, 195.

10 Ibidem, s. 91-97.
} 
Do sformułowania tej teorii przez Olsona przyczyniły się obserwacje sytuacji gospodarczej w krajach Zachodu i w Japonii po drugiej wojnie światowej. Intuicyjne rozumowanie wskazywałoby, że kraj, który poniósł ogromne straty ludnościowe, doświadczył znacznych strat materialnych, a do tego w wyniku drugiej wojny światowej znalazł się na pewien czas pod okupacją, powinien borykać się przez dłuższy czas z poważnymi trudnościami gospodarczymi. Tymczasem zarówno w Niemczech, jak i Japonii można było obserwować nie tylko szybką odbudowę, lecz także dynamiczny wzrost gospodarczy w późniejszym okresie (w latach sześćdziesiątych i siedemdziesiątych). Jak pokazuje tabela 1, tempo rozwoju gospodarczego było w tych państwach wyraźnie wyższe niż w krajach zachodnich, które nie doświadczyły tak ogromnych zniszczeń (na przykład Wielka Brytania, Szwajcaria czy USA).

Tabela 1. Przeciętna roczna stopa wzrostu PKB per capita w cenach stałych (w \%)

\begin{tabular}{l|c|c|c}
\hline \multicolumn{1}{c|}{ Kraj } & $1950-1960$ & $1960-1970$ & $1970-1978$ \\
\hline Australia & $2,0^{\mathrm{a}}$ & $3,7^{\mathrm{b}}$ & $2,4^{\mathrm{c}}$ \\
\hline Belgia & $2,0^{\mathrm{d}}$ & 4,1 & 3,1 \\
\hline Dania & 2,5 & 3,9 & 2,2 \\
\hline Niemcy (RFN) & 6,6 & 3,5 & 2,4 \\
\hline Finlandia & 3,3 & 4,2 & 2,5 \\
\hline Francja & 3,5 & 4,6 & 3,0 \\
\hline Irlandia & $1,8^{\mathrm{e}}$ & 3,8 & $2,3^{\mathrm{f}}$ \\
\hline Włochy & 4,9 & 4,6 & $2,1^{\mathrm{g}}$ \\
\hline Japonia & $6,8^{\mathrm{h}}$ & 9,4 & 3,8 \\
\hline Kanada & 1,2 & 3,7 & 3,1 \\
\hline Nowa Zelandia & $1,7^{\mathrm{i}}$ & $2,2^{\mathrm{j}}$ & - \\
\hline Holandia & 3,3 & 4,1 & 2,3 \\
\hline Norwegia & 2,7 & 4,0 & 3,9 \\
\hline Austria & 5,7 & 3,9 & 3,8 \\
\hline Szwecja & 2,9 & 3,6 & 1,2 \\
\hline Szwajcaria & 2,9 & 2,8 & $-0,1$ \\
\hline Wielka Brytania & 2,3 & 2,3 & 2,0 \\
\hline USA & 1,2 & 3,0 & 2,0 \\
\hline
\end{tabular}

a. $1952-1960$, b. $1963-1970$, c. $1970-1976$, d. $1953-1960$, e. 1970-1977, f. 1951-1960, g. 1970-1977, h. $1952-1960$, i. $1954-1960$, j. $1960-1968$

Źródło: M. Olson, Aufstieg und Niedergang..., s. 7. 
Co więcej, kraje te lepiej niż większość gospodarek zachodnich, radziły sobie z tak zwaną stagflacją (połączenie wysokiej inflacji i stagnacji gospodarczej) w latach siedemdziesiątych ${ }^{11}$. Jak widać, również gospodarkę Francji i Włoch charakteryzował szybki wzrost. Amerykański ekonomista, wskazując ten pierwszy wypadek, pisze o licznych wojnach, niepokojach i wstrząsach wewnętrznych oraz okupacji, jakiej musiał stawić czoła ten kraj podczas drugiej wojny światowej. Jak więc możliwe, że Francja, wraz z Niemcami i Japonią, zdołała osiągnąć poziom rozwoju gospodarczego porównywalny z Wielką Brytanią, która cieszyła się wyraźnie większą stabilnością wewnętrzną?

Zdaniem Olsona wyjaśnieniem tego pozornego paradoksu jest to, że dramatyczne wydarzenia, takie jak rewolucja czy okupacja kraju, prowadzą przeważnie do poważnych zmian społecznych i przez to do rozbicia grup dystrybucyjnych i osłabienia ich wpły$w^{12}$. Ponieważ, jak już wspomniałem, koalicje dystrybucyjne mają przewagę wynikającą z tego, że są mniejsze i bardziej jednorodne, trend narastania ich potęgi jest przeważnie przerywany dopiero dzięki tego rodzaju gwałtownym zmianom społecznym. Mamy tu więc do czynienia z cyklicznością.

Podobne zjawiska można było obserwować, zdaniem Olsona, nie tylko w powojennej Europie. Dobrym przykładem jest Wielka Brytania, która jeszcze na początku XIX wieku rozwijała się szybko, jednak później, zdaniem Olsona, rosnące znaczenie wąskich grup interesu doprowadziło do spowolnienia tempa wzrostu gospodarczego. W tym samym czasie w Stanach Zjednoczonych wpływ grup dystrybucyjnych nie był jeszcze tak duży, dzięki czemu mogły one rozwijać się szybciej niż Wielka Brytania ${ }^{13}$. Amerykański badacz twierdził, że rozległe wpływy grup dystrybucyjnych w znacznej mierze wyjaśniają gospodarczy zastój w krajach muzułmańskich, w Chinach przed dojściem do władzy komunistów (silne gildie) czy w Indiach w czasach panowania brytyjskiego (system kastowy). Zdaniem Olsona podobne zjawiska występowały również w Babilonii, starożytnej Grecji i Bizancjum ${ }^{14}$.

Odmienny układ sił pomiędzy grupami dystrybucyjnymi a inkluzywnymi może występować również na poziomie państwa. Amerykański ekonomista uważał, że wyższe tempo wzrostu w południowych i zachodnich stanach USA w XX wieku również może być wyjaśnione dzięki jego teorii ${ }^{15}$. To samo dotyczy dziewiętnastowiecznej Anglii, gdzie nastąpił gwałtowny rozwój przemysłu we wcześniej peryferyjnych ośrodkach, takich jak Manchester, Leeds czy Glasgow. Grupy dystrybucyjne nie były tam tak silne, jak na przykład w Londynie, co sprzyjało powstaniu i rozkwitowi nowych gałęzi gospodarki ${ }^{16}$.

Jakie wnioski ze wskazanych obserwacji można wyciągnąć z punktu widzenia osób odpowiedzialnych za politykę państwa? Olson twierdzi, że głównym instrumentem, którym posługują się grupy dystrybucyjne, jest gospodarczy protekcjonizm. Dlatego właściwe jest prowadzenie polityki wolnego handlu i swobodnego przepływu czynników

\footnotetext{
11 Ibidem, s. 3.

12 Ibidem, s. 99-102.

13 Ibidem, s. 173, 191-192, 236-237.

14 Ibidem, s. 195-198, 204-208.

15 Ibidem, s. 138-145.

16 Ibidem, s. 162-165.
} 
produkcji pomiędzy krajami (co może doprowadzić na przykład do rozbicia krajowego kartelu). Amerykański ekonomista twierdzi między innymi, że napływ do kraju ponadnarodowych korporacji jest korzystny dla większości konsumentów i pracowników, a negatywny stosunek do tego zjawiska, prezentowany przez wiele związków zawodowych i organizacji konsumenckich, jest wynikiem wpływu propagandy grup dystrybucyjnych ${ }^{17}$.

Może być również właściwe wspieranie przez państwo koalicji inkluzywnych poprzez popieranie organizacji, takich jak na przykład związki zawodowe (łącznie z akceptacją de facto przymusowej przynależności do nich w niektórych branżach ${ }^{18}$.

Ogólnie rzecz ujmując, teoria Olsona, podobnie jak wiele innych teorii, które w znacznej mierze zrywały z wcześniej dominującym w naukach społecznych paradygmatem, wywołała ożywioną dyskusję - częściowo spotkała się z uznaniem, lecz można również odnaleźć liczne głosy krytyczne — na przykład Johna Chamberlina (1974) czy Russela Hardina (1982). Główną wadą teorii Olsona jest, moim zdaniem, przecenianie znaczenia niektórych czynników. Dotyczy to na przykład wpływu rywalizacji grup dystrybucyjnych i inkluzywnych na proces rozwoju i upadek społeczeństw. Na znaczne różnice w tempie wzrostu między USA a Wielką Brytanią w drugiej połowie dziewiętnastego wieku wpływ miało o wiele więcej czynników (warunki naturalne, system polityczny, początkowy poziom uprzemysłowienia itd.). Również wpływ polityki handlowej na rozwój gospodarczy jest, moim zdaniem, kwestią bardziej złożoną niż to wynikałoby $\mathrm{z}$ analizy Olsona. Jak stwierdził jeden $\mathrm{z}$ recenzentów Logiki działania zbiorowego, Olson „wyciągnął zbyt uniwersalne i daleko idące wnioski ze swojego prostego i opartego na dość arbitralnych założeniach modelu"19. Tendencja ta jest widoczna również w wypadku Wzrostu potegi i schyłku państw.

Innym często podnoszonym zarzutem był rzekomy brak oryginalności - Olson miał przedstawić w swoich pracach obserwacje, które już wcześniej zostały zaprezentowane przez uczonych i myślicieli politycznych (wiele elementów teorii Olsona można znaleźć jeszcze u Davida Hume’a, Alexandra Hamiltona, Jamesa Madisona czy Johna Stuarta Milla). Jednak niezaprzeczalną zasługą Olsona jest właśnie połączenie tych koncepcji $\mathrm{w}$ spójną teorię i zwrócenie na nie uwagi świata nauki ${ }^{20}$.

Przede wszystkim nie można odmówić pracom Olsona logicznej spójności. Ponadto mnogość przykładów historycznych przytoczonych przez amerykańskiego ekonomistę dowodzi, iż rzeczywiście bardzo często długotrwała społeczna stabilizacja przekształca się w stagnację czy regres. Wzrost znaczenia wąskich grup interesu, zabiegających o własne korzyści i w znacznej mierze ignorujących kwestie „dobra wspólnego” (co, jak wykazał Olson, wynika z ekonomicznej racjonalności, a nie ze „skaz charakteru” poszczególnych ludzi) w dużym stopniu wyjaśnia ten proces.

17 Ibidem, s. 186-192.

18 M. Olson, The Logic of Collective Action..., s. 88-97.

19 Ł. Ostrowski, Recenzja książki Mancura Olsona „Logika działania zbiorowego. Dobra publiczne i teoria grup”, „Decyzje” 2012, nr 18, s. 117-121.

20 K. Dougherty, Public goods theory from eighteenth century political philosophy to twentieth century economic, „Public Choice” 2003, nr 117 s. 239-253. 
Jednak właściwe wydaje się uwzględnienie głosów krytycznych i rezygnacja z pretensji do wyjaśniania zjawisk społecznych za pomocą jego teorii „zawsze i wszędzie” (a więc na przykład w starożytności). Bardziej racjonalne wydaje się rozważenie, w jakim stopniu konkretna sytuacja odpowiada modelowi teoretycznemu przedstawionemu przez Olsona.

\section{Sytuacja w krajach Europy Zachodniej z perspektywy teorii Olsona}

Niemal wszystkie kraje zachodniej Europy doświadczyły po drugiej wojnie światowej długotrwałego okresu stabilności społecznej i politycznej. Fakt ten jest najczęściej przedstawiany wyłącznie w pozytywnym świetle. Rzeczywiście trudno uznać związane z tym bezpieczeństwo i wysoki standard życia za coś niepożądanego. Jednak w kontekście teorii Olsona sytuacja ta ma również swoją negatywną stronę, gdyż stanowi idealną sposobność do kumulowania się koalicji dystrybucyjnych, co powinno prowadzić do spadku tempa rozwoju gospodarczego.

Jeśli chodzi o dane przedstawione $\mathrm{w}$ tabeli 2 , trudno wyciągnąć $\mathrm{z}$ nich tak jednoznaczne wnioski, jak w wypadku tabeli 1. W wypadku krajów wysokorozwiniętych w ostatnich latach nie mamy możliwości porównania sytuacji państw, w których nastąpiły gwałtowne zmiany społeczne, z sytuacją krajów, w których takie zmiany nie nastąpiły, ponieważ wszystkie państwa niezmiennie cechowały się wysokim stopniem stabilności.

Tabela 2. Przeciętna roczna stopa wzrostu PKB per capita w cenach stałych (w \%)

\begin{tabular}{l|c|c|c}
\hline \multicolumn{1}{c|}{ Kraj } & $1990-2000$ & $2000-2010$ & $2010-2016$ \\
\hline Niemcy & 1,6 & 1,0 & 0,9 \\
\hline Francja & 1,7 & 0,6 & 0,3 \\
\hline Wielka Brytania & 2,2 & 0,9 & 0,8 \\
\hline Włochy & 1,6 & $-0,1$ & $-0,4$ \\
\hline USA & 2,2 & 0,7 & 0,8 \\
\hline Japonia & 1,1 & 0,5 & 0,7 \\
\hline
\end{tabular}

Źródło: obliczenia własne na podstawie bazy danych Banku Światowego: http://data.worldbank.org. (dostęp: 12.04.2018).

Warto jednak zwrócić uwagę, że gospodarki, które w latach sześćdziesiątych i siedemdziesiątych charakteryzował wyjątkowo wysoki wzrost, takie jak Niemiec, Francji czy Włoch, zupełnie zatraciły swoją przewagę względem USA i Wielkiej Brytanii. Podobna sytuacja dotyczy Japonii. Najbardziej wymowny jest przypadek Włoch. Jeszcze w latach siedemdziesiątych mówiono o tak zwanym miracolo, czyli włoskim „cudzie gospodarczym”. W latach dziewięćdziesiątych kraj ten wszedł w okres wolnego wzrostu, który w następnej dekadzie zamienił się w powolny regres. Jest to dość rzadki przypadek tak długiego okresu osłabienia gospodarczego niespowodowanego żadnymi dramatycznymi wydarzeniami 
(wojna, niepokoje społeczne, gwałtowna zmiana polityki wewnętrznej). Trudno wyjaśnić to zjawisko, gdyż w latach 2000-2016 miał miejsce wyraźny postęp technologiczny i choćby ten czynnik powinien spowodować przynajmniej powolny wzrost.

$\mathrm{W}$ żadnym $\mathrm{z}$ krajów wymienionych $\mathrm{w}$ tabeli 2 nie zaszły również istotne zmiany strukturalne, które mogłyby kompensować niekorzystne tendencje towarzyszące stagnacji (gdyby na przykład doszło do znacznych zmian w systemie gospodarczym w kierunku poprawy realnych standardów życia kosztem spowolnienia wzrostu produkcji, można by uznać taką sytuację za korzystną).

Utrata przez kraje kontynentalnej Europy Zachodniej przewagi gospodarczej względem USA i Wielkiej Brytanii jest jednak zjawiskiem jak najbardziej spójnym z przedstawioną w poprzednim podrozdziale teorią Olsona.

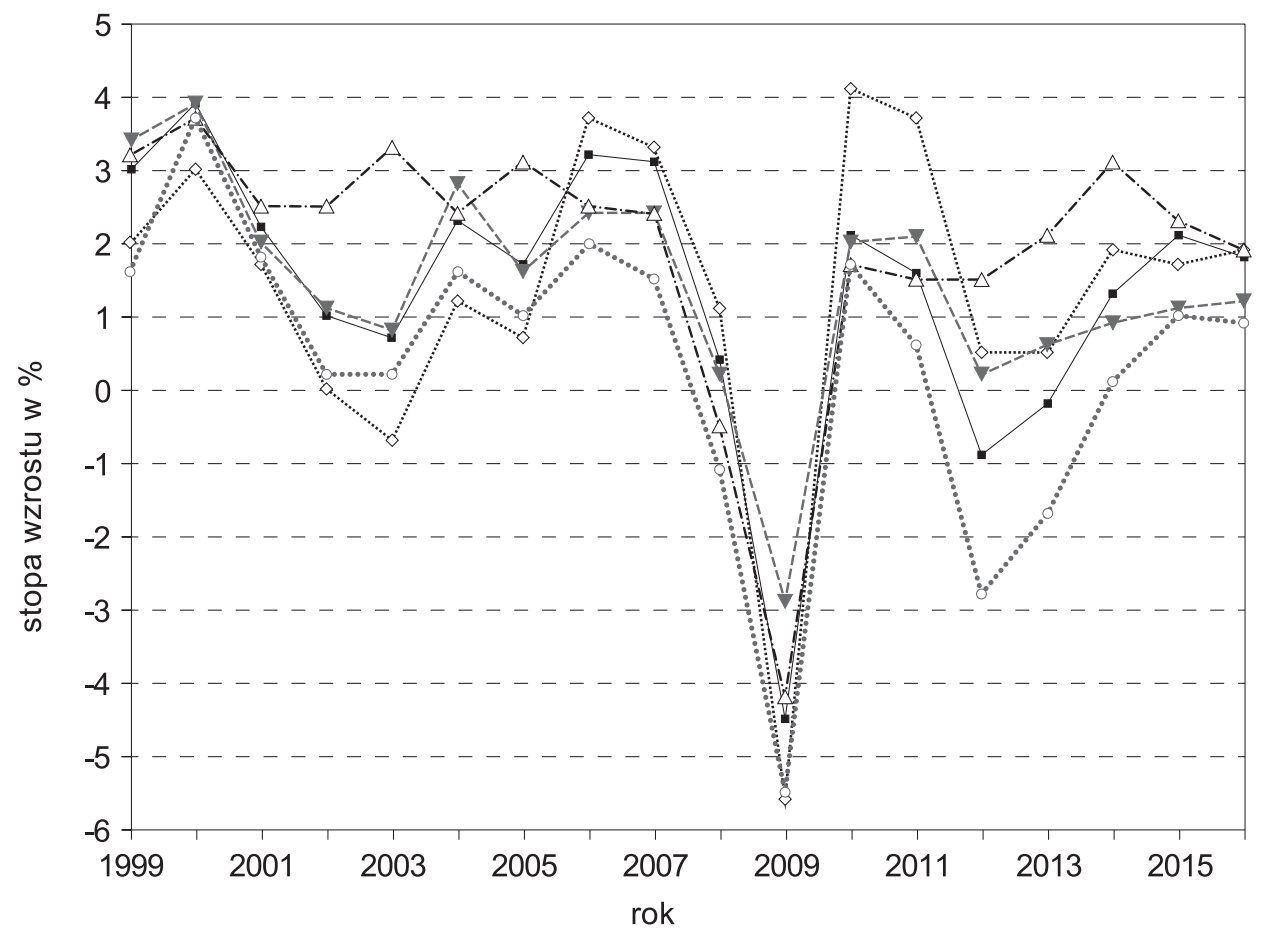

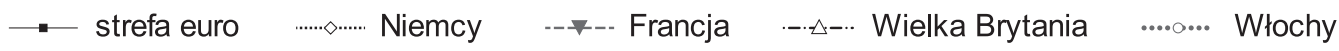

Wykres 1. Wzrost gospodarczy w strefie euro i wybranych krajach UE w latach 1996-2016

Źródło: opracowanie własne na podstawie bazy danych Banku Światowego, http://data.worldbank.org (dostęp: 12.04.2018).

Przewaga wynikająca $\mathrm{z}$ rozbicia grup dystrybucyjnych w wyniku dramatycznych przemian społecznych nie może być trwała, gdyż dość szybko dochodzi do ponownego wzrostu ich znaczenia. Jest więc prawdopodobne, że po upływie kilkudziesięciu lat liczba i wpływ koalicji dystrybucyjnych w takich krajach, jak Niemcy, Włochy, Francja, są porównywalne lub nawet większe niż w USA czy Wielkiej Brytanii. 
Tabela 3. Organizacje lobbingowe o największej liczbie spotkań na najwyższym szczeblu w instytucjach Unii Europejskiej. Dane za okres grudzień 2014-czerwiec 2015 (kolorem szarym oznaczono organizacje o typowo „dystrybucyjnym” charakterze)

\begin{tabular}{|c|c|c|c|c|}
\hline Pozycja & Nazwa & Spotkania & $\begin{array}{l}\text { Budżet lobbingowy } \\
\text { (EUR) }\end{array}$ & $\begin{array}{c}\text { Liczba } \\
\text { lobbystów }\end{array}$ \\
\hline 1. & BUSINESSEUROPE & 42 & 4000000 & 29 \\
\hline 2. & Google & 29 & 3500000 & 9 \\
\hline 2. & WWF European Policy Programme & 29 & 1000000 & 12 \\
\hline 4. & General Electric Company (GE) & 26 & 3250000 & 9 \\
\hline 4. & EuroCommerce & 26 & 400000 & 3 \\
\hline 6. & $\begin{array}{l}\text { European Chemical Industry } \\
\text { Council }\end{array}$ & 25 & 10100000 & 45 \\
\hline 6. & Airbus Group N.V. & 25 & 400000 & 10 \\
\hline 8. & Greenpeace European Unit & 22 & 1000000 & 7 \\
\hline 8. & $\begin{array}{l}\text { American Chamber of Commerce } \\
\text { to the European Union (AmCham } \\
\text { EU) }\end{array}$ & 22 & 900000 & 6 \\
\hline 8. & $\begin{array}{l}\text { Climate Action Network Europe } \\
\text { (CAN Europe) }\end{array}$ & 22 & 800000 & 11 \\
\hline 8. & $\begin{array}{l}\text { The European Steel Association } \\
\text { (EUROFER) }\end{array}$ & 22 & 600000 & 2 \\
\hline 8. & $\begin{array}{l}\text { EUROCHAMBRES - Association } \\
\text { of European Chambers of } \\
\text { Commerce and Industry } \\
\text { (eurochambres) }\end{array}$ & 22 & 7600000 & 18 \\
\hline 13. & $\begin{array}{l}\text { Bureau Européen des Unions de } \\
\text { Consommateurs (BEUC) }\end{array}$ & 20 & 1500000 & 16 \\
\hline 13. & $\begin{array}{l}\text { OXFAM INTERNATIONAL EU } \\
\text { ADVOCACY OFFICE }\end{array}$ & 20 & 300000 & 12 \\
\hline
\end{tabular}

Źródło: Raport Transparency International dotyczący lobbingu w UE w 2014 roku: Lobby meetings with EU policymakers dominated by corporate interests, http://www.transparency.org/news/pressrelease/lobby_meetings_with_eu_ policy_makers_dominated_by_corporate_interests (dostęp: 11.04.2018).

Czy dysponujemy jednak dowodami na szczególny wpływ tego rodzaju grup na instytucje krajów Europy Zachodniej? Ograniczona objętość niniejszego artykułu nie pozwala na przeanalizowanie sytuacji w poszczególnych krajach, nie uważam również, by było to konieczne. W swojej analizie postanowiłem skupić się na instytucjach Unii Europejskiej jako mających istotny wpływ na sytuację w wymienionych państwach. Ze względu na kluczowe znaczenie najsilniejszych gospodarczo krajów Europy Zachodniej, jeśli chodzi o kształtowanie polityki Brukseli, sytuację w instytucjach UE można w znacznej mierze uznać za odzwierciedlenie stosunków panujących w tych krajach. 
Przede wszystkim warto zauważyć, że skomplikowany proces decyzyjny w kluczowych instytucjach Unii Europejskiej oraz tendencja do zawierania kompromisów i uwzględniania głosu wszystkich państw członkowskich są prawdopodobnie korzystne dla grup dystrybucyjnych, które mogą na przykład blokować niekorzystne dla siebie decyzje dzięki uzyskaniu wpływu na stanowisko jednego z krajów członkowskich.

Tabela 3 przedstawia oficjalne dane dotyczące wpływu różnych grup na działalność instytucji UE. Jak widać, aktywność grup typowo dystrybucyjnych jest bardzo duża. Trudno oszacować jej skuteczność, lecz można przypuszczać, że wielkie korporacje nie ponosiłyby nakładów liczonych w wielu mln EUR, gdyby nie przynosiło to określonych korzyści.

Należy zaznaczyć, że wymienione w tabeli organizacje mające pozornie inkluzywny charakter (na przykład stowarzyszenia biznesowe i handlowe) również były postrzegane przez autorów raportu jako reprezentujące „korporacyjne interesy”. Ponadto zestawienie nie oddaje pełnej skali zjawiska, gdyż lobbyści korporacyjni przedstawiali bardzo często niepełne lub niewiarygodne dane ${ }^{21}$.

Dokładniejszy obraz wpływu wąskich grup interesu przedstawia, wydana pod auspicjami organizacji zajmujących się monitorowaniem lobbingu w UE, publikacja pod tytułem Przebijając brukselska bańkę. Walka w celu ujawnienia lobbingu korporacyjnego $w$ sercu $U E^{22}$. Zdaniem autorów widoczna jest stała tendencja do wzrostu znaczenia lobbystów w Unii Europejskiej, przy czym jedynie niewielka część z nich reprezentuje szersze interesy. Powołują się oni na szacunki, zgodnie z którymi lobbystów korporacyjnych jest pięć razy więcej niż tych zabiegających o dobro publiczne. Ponadto ci pierwsi dysponują lepszym finansowaniem i są faktycznie uprzywilejowani w dostępie do osób podejmujących decyzje ${ }^{23}$. Przedstawiono również przykłady, gdy stanowisko Parlamentu Europejskiego w budzących kontrowersje kwestiach było niemal identyczne z propozycjami poszczególnych lobby branżowych. Dotyczyło to takich spraw, jak testowanie leków na zwierzętach, ograniczenie emisji gazów cieplarnianych oraz wprowadzenie systemu testowania i rejestrowania chemikaliów ${ }^{24}$. Rywalizację grup walczących o interesy publiczne z lobbystami korporacyjnymi przedstawiono jako „walkę Dawida z Goliatem” (oczywiście to przedstawiciele wielkiego biznesu są tu „Goliatem”), przy czym nierównowaga dotyczy zarówno zasobów, jakimi dysponują obie strony, jak i rzeczywistych rezultatów aktywności ${ }^{25}$.

Choć, jak wspomniałem, nie jest możliwe dokonanie szczegółowej analizy sytuacji w poszczególnych krajach, można zauważyć, że problemy opisywane przez M. Olsona związane z silną pozycją uprzywilejowanych grup zostały dostrzeżone przez ekonomi-

${ }^{21}$ Lobby meetings with EU policy-makers dominated by corporate interests, http:www.transparency.org/ news/pressrelease/lobby_meetings_with_eu_policy_makers_dominated_by_corporate_interests (dostęp: 11.04.2018).

${ }^{22}$ H. Burley, Bursting the Brussels Bubble. The Battle to Expose Corporate Lobbying at the Heart of the EU, Bruksela 2010.

${ }^{23}$ Ibidem, s. 24.

24 Ibidem, s. 27-28.

25 Ibidem, s. 28-31. 
stów w wielu krajach Unii Europejskiej. Dotyczy to przede wszystkim państw, w których długotrwałe trudności ekonomiczne występowały ze szczególnym natężeniem, takich jak Francja, Włochy czy Grecja. Na przykład raport Międzynarodowego Funduszu Walutowego wśród przeszkód na drodze do zwiększenia tempa wzrostu gospodarczego we Francji wymienia takie kwestie, jak przywileje grup zawodowych (architektów, notariuszy, aptekarzy) w postaci ograniczeń w dostępie do wykonywania zawodu czy ograniczenia w prowadzeniu określonych rodzajów działalności gospodarczej (na przykład usług transportowych czy handlu lekami). Szacowano przy tym, że reformy w tych obszarach mogłyby przynieść zwiększenie tempa wzrostu o około $0,3 \%$ rocznie w ciągu najbliższych 5 lat ${ }^{26}$. Również w raportach Międzynarodowego Funduszu Walutowego dotyczących sytuacji we Włoszech zwrócono uwagę na uprzywilejowaną pozycję niektórych grup zawodowych i regulacje chroniące wybrane sektory gospodarki, co ograniczało dostępność oferowanych przez nie usług i produktów. Wskazano ponadto, że władze podjęly próby usunięcia tych ograniczeń, lecz działania te napotkały poważne przeszkody w parlamencie ${ }^{27}$. W wypadku Grecji eksperci MFW zwrócili uwagę, że pomimo podjętych reform jest ona wciąż jednym z najbardziej restrykcyjnych krajów OECD, jeśli chodzi o takie kwestie, jak ograniczenia w dostępie do zawodów czy licencje na prowadzenie określonych rodzajów działalności gospodarczej ${ }^{28}$.

Trzeba jednak zastrzec, że eksperci MFW przedstawiają problemy związane z funkcjonowaniem grup dystrybucyjnych jako jedne z wielu przeszkód na drodze do zdynamizowania wzrostu gospodarczego (obok na przykład zbyt restrykcyjnego prawa pracy, złej polityki fiskalnej czy nieefektywnej administracji), a nie główną przyczynę stagnacji, tak jak jest to w wypadku teorii Olsona. Warto jednak zauważyć, że ekonomiści MFW skoncentrowali się w swoich analizach na barierach tworzonych przez pewne określone kategorie grup interesu (głównie korporacje zawodowe) lub też na najbardziej „jaskrawych" przykładach ograniczeń w dostępie do rynku (na przykład licencje czy inne przeszkody administracyjne $\mathrm{w}$ prowadzeniu działalności gospodarczej). Pominięto natomiast kwestie związane $\mathrm{z}$ wpływem lobbyingu korporacyjnego na ustawodawstwo i politykę państwa (przy czym w tym wypadku o wiele trudniej ocenić negatywne skutki z punktu widzenia całego społeczeństwa i gospodarki).

\section{Podsumowanie}

W tym miejscu przypomnę brzmienie głównej tezy, którą chciałem zweryfikować w swoim artykule: problemy gospodarcze i polityczne krajów Europy Zachodniej mają w istocie

${ }^{26}$ Ponieważ ekonomiści nie dysponują modelem odzwierciedlającym rzeczywiste funkcjonowanie gospodarki w całej jej złożoności, tego rodzaju wyliczenia należy traktować jako szacunkowe. Choć może się wydawać, że przedstawiona liczba nie ma większego znaczenia z punktu widzenia rozwoju w perspektywie dekady, to biorąc pod uwagę, że gospodarka Francji balansowała w ostatnich latach na granicy recesji, może ona rozstrzygnąć o tym, czy gospodarka będzie odnotowywała powolny wzrost, czy też będziemy obserwowali regres. J.J. Hallaert et al., IMF Country Report Nr 15/179: France, Washington 2015, s. 22-23.

27 IMF Country Report Nr 17/237: Italy, Washington 2017, s. 13.

28 IMF Country Report Nr 18/248: Greece, Washington 2018, s. 17. 
głębsze podłoże natury społecznej. Ponadto można przypuszczać, że mamy do czynienia z długotrwałymi procesami, które wcale nie są bezprecedensowe, lecz występowały już wcześniej w innych krajach i epokach.

Uważam, że teza została w znacznej mierze pozytywnie zweryfikowana. Świadczą o tym następujące przesłanki:

1. Sytuacja w krajach Europy Zachodniej odpowiada tej opisanej w teorii Olsona dotyczącej rozwoju i upadku społeczeństw - prawdopodobne więc, że mamy do czynienia $\mathrm{z}$ większym procesem społecznym, a nie jedynie przejściowymi trudnościami natury politycznej czy gospodarczej.

2. Zgodnie z teorią można obserwować stagnację gospodarczą i trudności w przeprowadzaniu poważnych zmian systemowych.

3. Możemy wskazać konkretne zjawiska będące przejawem tych szerszych procesów (silna pozycja wąskich grup interesu w procesie decyzyjnym w UE).

Oczywiście pozostają pewne wątpliwości dotyczące skali opisywanych zjawisk i dokładnych zależności pomiędzy nimi. Można na przykład postawić pytanie: czy rzeczywiście negatywny wpływ wąskich grup interesu jest aż tak silny, by powodować znaczne trudności gospodarcze?

Jednak jest to problem, który chyba nie może być całkowicie rozwiązany, gdyż nie dysponujemy żadnym matematycznym modelem funkcjonowania społeczeństw, który umożliwiłby dokładne określenie natężenia poszczególnych zjawisk.

Niemniej jednak należy pamiętać, że mamy do czynienia z niezwykle złożonym systemem i błędem byłoby ograniczanie się do wyjaśniania złożonych procesów tylko za pomocą jednego czynnika. Nie uważam więc, że teoria Olsona jest jedynym wyjaśnieniem kryzysu, w jakim znalazły się kraje Europy Zachodniej, lecz cykliczne procesy opisywane przez amerykańskiego ekonomistę można zaobserwować również we współczesnej Europie.

Ponadto sądzę, że teoria ta może być wykorzystana do wyjaśnienia zmian tempa rozwoju w różnych krajach i epokach. Warto rozważyć jej przydatność, szczególnie jeśli chodzi o wytłumaczenie szybszego tempa rozwoju po okresie wewnętrznej niestabilności i gwałtownych zmian społecznych, nawet gdy system gospodarczy danego państwa nie charakteryzował się wysoką efektywnością. Może to dotyczyć na przykład powojennej Polski czy Chin wychodzących z okresu niepokojów wewnętrznych lat siedemdziesiątych i osiemdziesiątych. Jest to, moim zdaniem, hipoteza wymagająca głębszego zbadania.

Jeśli zaakceptujemy proponowane wyjaśnienie panującej w krajach Europy Zachodniej stagnacji, to wynikają z tego dalsze implikacje.

Zakładając, że mamy do czynienia z długotrwałym i mającym głębokie podstawy procesem będącym elementem cyklu rozwoju i upadku społeczeństw, trudno oczekiwać, by obecne trudności mogły być przezwyciężone dzięki prostym zmianom politycznym. $\mathrm{Na}$ tej podstawie można prognozować, że kolejne programy reform mających na celu wyjście z obecnej stagnacji (na poziomie zarówno UE, jak i państw narodowych) nie spełnią pokładanych w nich oczekiwań (o ile w ogóle uda się je przeprowadzić). Zresztą tego rodzaju sytuację można było obserwować na Starym Kontynencie w ciągu ostatnich 20 lat 
wielokrotnie, o czym świadczy fiasko kolejnych projektów integracyjnych i powszechne rozczarowanie co do efektów wprowadzenia wspólnej europejskiej waluty.

$\mathrm{Z}$ teorii Olsona wynika również, że nie jest możliwa realizacja trwałego projektu politycznego na podstawie kompromisowych porozumień uwzględniających interesy różnych wąskich grup. W efekcie przyjęcia takiej strategii pewna liczba „koalicji dystrybucyjnych" realizuje swoje interesy, jednak dzieje się to kosztem interesów reszty społeczeństwa. Skutkiem jest spadek efektywności funkcjonowania całego systemu. Obserwacje te skłaniają do krytyki obecnego kształtu projektu integracji europejskiej, w którym kładzie się nacisk na osiągnięcie kompromisu między interesami rożnych grup, długotrwałą „deliberację" i zasadniczo pojawia się tendencja do wydłużania procesu decyzyjnego, co stwarza niezwykle korzystne warunki działalności różnego rodzaju lobbies.

Warto zwrócić uwagę, że w zainteresowaniu wąskich grup interesu znajdują się najczęściej niewielkie wycinki rzeczywistości społecznej. Na przykład lobby przemysłu farmaceutycznego interesuje się regulacjami dotyczącymi produkcji leków, ale raczej nie będzie poświęcać uwagi kwestiom, dajmy na to, związanym z polityką energetyczną. $\mathrm{W}$ ten sposób może powstać wrażenie, że tego rodzaju działalność nie ma większego znaczenia z punktu widzenia całego społeczeństwa. Zasługą Olsona jest dostrzeżenie, że jest ona częścią szerszego zjawiska, które narasta z czasem, jego rezultaty „kumulują się”, a przeciwdziałanie jest niezwykle trudne.

Z obserwacji amerykańskiego ekonomisty wynika, że „europejska kultura stabilności", o jakiej mówił Mario Monti, może być nie jednym z głównych atutów Starego Kontynentu, lecz jedną z istotnych przyczyn problemów, z którymi się on boryka. W każdym razie bilans korzyści i strat z niej wynikających nie jest tak jednoznacznie pozytywny, jak wskazywałoby intuicyjne rozumowanie.

Mam nadzieję, że niniejsza praca wydała się czytelnikowi interesująca i inspirująca intelektualnie. Niestety ze względu na jej ograniczoną objętość byłem zmuszony pominąć niektóre wątki, które uważam za warte dokładniejszego zbadania. Jednak myślę, że teoria Mancura Olsona, po kilkudziesięciu latach od jej sformułowania, wciąż jest przydatnym narzędziem do wyjaśniania procesów zachodzących we współczesnych społeczeństwach.

\section{Bibliografia}

Baza danych Banku Światowego, 2018, data.worldbank.org.

Burley H., Bursting the Brussels Bubble. The Battle to Expose Corporate Lobbying at the Heart of the EU, Bruksela 2010.

Chamberlin J., Provision of collective goods as a function of group size, „American Political Science Review” 1974, nr 68.

Dougherty K., Public goods theory from eighteenth century political philosophy to twentieth century economic, „Public Choice” 2003, nr 117.

Elliott L., Wearden G., Merkel and Sarkozy Push for greater European co-operation. European summit calls for creation of eurozone president and balanced budgets, „The Guardian” 17.08.2011, http://www.theguardian.com/business/2011/aug/17/angela-merkel-nicolas-sarkozy-summit. 
Hallaert J.J., Perez-Ruiz E., Gorbanyov M., Kongsamut P., IMF Country Report Nr 15/179: France, Washington 2015.

Hardin R., Collective Action, Baltimore 1982.

IMF Country Report Nr 17/237: Italy, Washington 2017.

IMF Country Report Nr 18/248: Greece, Washington 2018.

Lobby meetings with EU policy-makers dominated by corporate interests, http://www.transparency.org/news/ pressrelease/lobby_meetings_with_eu_policy_makers_dominated_by_corporate_interests.

Olson M., Aufstieg und Niedergang von Nationen, Tybinga 1985.

Olson M., The Logic of Collective Action. Public Goods and the Theory of Groups, Cambridge 2002.

Ostrowski Ł., Recenzja książki Mancura Olsona „Logika działania zbiorowego. Dobra Publiczne i teoria grup”, „Decyzje” 2012, nr 18.

Przemówienie wygłoszone przez M. Montiego 27 listopada 1998 roku na konferencji „Kangaroo Group”, europa.eu/rapid/press-release_SPEECH-98-272_en.htm.

Sarkozy eyes two-speed future for Europe, „Reuters” 8.11.2011, http://www.reuters.com/article/usfrance-eurozone/sarkozy-eyes-two-speed-future-for-europe-idUSTRE7A75PN20111108.

\section{Current problems in West European countries from the perspective of Mancur Olson's theory}

Keywords: collective action, vested interests, lobbying, Olson, EU, eurozone, economic crisis

\section{Summary}

This paper employs the theory of collective action created by the American economist Mancur Olson, to examine the current problems of Western European countries and their causes. The article focuses on economic and political issues, such as economic stagnation, the inability to introduce reforms and the failure of ambitious European integration projects. The study contains an analysis of economic performances of West European countries in the post-war period and attempts to assess the influence of lobby groups on decision making in the European institutions. It is argued that the growing influence of powerful lobby groups and vested interests can account for the declining economic efficiency and inability of political institutions to solve this problem. 